\title{
PENGEMBANGAN MEDIA PEMBELAJARAN PENDIDIKAN AGAMA ISLAM (PAI) BERBASIS WEB DI KELAS VIII SMP UNISMUH MAKASSAR
}

\author{
P-ISSN: 2089-4341 | E-ISSN: 2655-9633 \\ Link: https://uia.e-journal.id/akademika/article/view/813 \\ DOI: $\underline{10.34005 / a k a d e m i k a . v 9 i 01.813}$ \\ Nasir \\ nasir@unismuh.ac.id \\ Universitas Muhammadiyah Makassar-Indonesia
}

\begin{abstract}
Abstrac: This research aims to determine the results of the development of web-based learning media for Islamic Religious Education (PAI) which is valid and practical. This learning media development model refers to the 4-D development model (Four D-Model). This research was conducted at Unismuh Makassar Junior High School with research subjects 30 students and 1 teacher Islamic Education. The instruments used were validation sheets, student activity, teacher response and students. The data collection techniques used observation sheet instruments and student and teacher response questionnaires. The analysis used is descriptive qualitative statistical analysis. Based on the results of research and development shows that the media developed after validation is declared valid and reasonable for testing. The results of testing practicality show that the web-based learning media is practical because it has fulfills the criteria with the results: 1) students' activities in learning are carried out as expected, 2) teachers give excellent responses and, 3) students provide good response to the learning media. So it can be concluded that in the development of learning media activities fulfill valid and practical criteria used in the learning process especially in PAl subjects in class VIII.
\end{abstract}

Keywords: Development, web learning media, Islamic Religious Education

\begin{abstract}
Abstrak: Penelitian ini bertujuan untuk mengetahui hasil pengembangan media pembelajaran Pendidikan Agama Islam (PAl) berbasis web yang valid dan praktis. Model pengembangan yang digunakan adalah model pengembangan 4-D (Four D-Model). Penelitian ini dilaksanakan di SMP Unismuh Makassar dengan subjek penelitian 30 siswa dan 1 guru PAI. Instrumen yang digunakan adalah lembar validasi, aktivitas siswa, respon guru dan siswa. Teknik pengumpulan data yang digunakan instrument yaitu lembar observasi dan angket respon guru dan siswa. Analisis yang digunakan adalah analisis statistik deskriptif kualitatif. Berdasarkan hasil penelitian dan pengembangan menunjukkan bahwa media yang dikembangkan dinyatakan valid dan layak uji coba. Hasil uji coba kepraktisan menunjukkan bahwa media pembelajaran berbasis web praktis karena telah memenuhi keriteria dengan hasil: 1) aktivitas siswa dalam pembelajaran terlaksana dengan baik sesuai yang diharapkan, 2) guru memberikan respon sangat baik dan, 3) siswa memberikan respon baik terhadap media pembelajaran.Sehingga dapat disimpulkan bahwa dalam kegiatan pengembangan media pembelajaran memenuhi kriteria valid dan praktis digunakan dalam proses pembelajaran khususnya pada pelajaran PAI di kelas VIII.
\end{abstract}

Kata kunci: Pengembagan, Media Pembelajaran Web, Pendidikan Agama Islam 


\section{PENDAHULUAN}

Perkembangan teknologi informasi yang semakin pesat di era globalisasi saat ini tidak dapat dihindari lagi pengaruhnya terhadap dunia pendidikan, sehingga peran pemerintah perlu senantiasa melakukan penyesuaian untuk peningkatan mutu pendidikan. Upaya peningkatan mutu pendidikan dapat dilakukan yaitu dengan melalui penyesuaian penggunaan Teknologi Informasi dan Komunikasi (TIK ) memungkinkan akan memberikan peluang besar terhadap peningkatan kualitas pembelajaran. Dalam hal ini berarti tuntutan proses penyampaian pembelajaran diharapkan berlangsung secara efektif yang ditandai dengan penggunaan alat dan sumber belajar relatif kecil.

Aktifitas pembelajaran modern mengacu paradigma pembelajaran berpusat pada siswa (student-centered learning) yang memberikan kesempatan siswa dominan berperan aktif baik menyelesaikan tugas tugas mata pelajaran maupun mencari informasi melalui sumber belajar. Sedangkan guru berperan sebagai fasilitator, motivator, dan evaluator pembelajaran. Sehingga baik guru maupun siswa masing - masing miliki peran tertentu.

Adapun metode penyampaian denga menggunakan media pembelajaran akan mendorong mengalihkan posisi seorang guru sebagai sumber informasi utama menjadi seorang fasilitator para siswa baik di dalam maupun di luar kelas. Penggunaan media dalam pembelajaran sangat diutamakan guna menimbulkan minat belajar, motivasi belajar, merangsang siswa berperan aktif dalam proses pembelajaran. Melalui penggunaan media diharapkan dapat lebih mempermudah menyampaikan materi yang diberikan dan dapat meningkatkan kualitas pembelajaran. Menurut Edgar Dale (dalam Azhar Arsyad, 2011) pada krucut pengalaman jenjang yang paling konkrit ke yang paling abstrak dengan dimulai dari siswa yang berpartisipasi dalam pengalaman nyata, kemudian menuju siswa sebagai pengamat kejadian nyata, dilanjutkan ke siswa sebagai pengamat terhadap kejadian yang disajikan dengan media, dan terakhir siswa sebagai pengamat kejadian yang disajikan dengan simbol (lambang) sehingga siswa dapat untuk menentukan sendiri pengalaman belajarnya. Oleh karena itu, media pembelajaran sangatlah penting sebagai sarana penyampaian materi dalam proses pembelajaran oleh guru terhadap siswa.

Namun pada kenyataanya di lapangan masih banyak guru dalam penyampaln materi dengan metode konvesional. Guru dalam penyampaian materi metode konvensional kurang memanfaatkan media dan kurang inovatif sehingga pembelajaran belum optimal. Kondisi ini yang terjadi pada sekolah SMP Unismuh Makassar khususnya pada mata pelajaran Pendidikan Agama Islam (PAl).

Salah satu alasan guru kurang memanfaatkan media adalah kurangnya pengetahuan tentang penggunaan media, sehingga guru menyampaikan materi pembelajaran secara klasikal dengan metode 
ceramah. Hal inilah yang cenderung membuat siswa jenuh yang pada akhirnya menjadi pasif dalam menerima pelajaran. Pada saat kegiatan pembelajaran berlangsung di kelas, siswa menunjukka ketidaktarikannya. Ketika guru menjelaskan materi pelajaran, terlihat banyak siswa yang kurang berminat dan kurang termotivasi untuk belajar sehingga siswa melakukan aktivitas yang lain. Ketika siswa ditanya mengenai penggunaan media dalam proses pembelajaran mereka menjawab bahwa guru menggunakan media akan tetapi kurang menarik. Sehingga kami (siswa) kurang termotivasi untuk belajar. Padahal fasilitas sekolah mendukung penggunaan media pembelajaran seperti adanya wifi, proyektor, komputer/laptop, dan lain - lain. Kompleksnya permasalahan dalam mata pelajaran Pendidikan Agam Islam ( PAI ) berdampak terhadap hasil belajar. Pembelajaran PAI tidak boleh dilangsungkan dengan asalasalan. Maksudnya adalah PAI ini tidak boleh dilaksanakan tanpa persiapan yang matang, tidak memiliki konsep manajemen pembelajaran yang jelas, monoton, membosankan, atau hal-hal lain yang serupa dengan keadaan negatif. Jika hal tersebut dilakukan, maka akan berimplikasi pada kualitas pembelajaran PAI yang diselenggarakan, yang pada ujungnya mempengaruhi ketercapaian tujuan PAI itu sendiri (Khairan \& Verawati, 2017).

Upaya yang dapat dilakukan untuk peningkatan kualitas pembelajaran melalui pemanfaatan teknologi pembelajaran berbasis web (e-learning). Dalam teknologi pembelajaran, media merupakan sarana pendukung terhadap proses pembelajaran. Menurut Association For Education and Communicatioan/AECT (dalam Muslim, 2018) media adalah segala bentuk yang diprogramkan untuk suatu proses penyalaran informasi). Web merupakan sebuah jaringan dari jaringan - jaringan yang memungkinkan untuk mengakses, melihat dan menyimpan dokumen yang bisa meliputi teks, data, suara, dan video (Sharon E Semaldinho. dkk, 2011). Media pembelajaran berbasis web suatu kegiatan pembelajaran yang memanfaatkan media situs yang bisa diakses melalui jaringan internet. Online learning adalah fasilitas jaringan global untuk menyampaikan materi ajar serta memanfaatkannya untuk berkomunikasi antara guru dan siswa, siswa dan sumber belajar (Dabbagh \& Banna Ritland, 2005 dalam Dewi Salma, 2012). Media pembelajaran tersebut merupakan suatu sistem yang dapat memfasilitasi guru dan siswa belajar secara mandiri, bervariasi, dan menyenangkan. Web mempunyai potensi dikembangkan sebagai media pembelajaran. Setidaknya materi dalam web tersebut bisa memperkaya pengetahuan di luar proses pembelajaran secara tatap muka. Selain itu, melalui web materi bisa tersaji lebih menarik, Sebab web bisa dilengkapi dengan grafis, ilustrasi/gambar/foto, video, dan lain-lain.

Dari berbagai pendapat diatas web memiliki potensi untuk dikembangkan sebagai media pembelajaran karena melalui web yang bisa di akses kapan dan dimana saja, proses pembelajaran siswa menjadi tidak terbatas pada jam belajar efektif yang tersedia di sekolah. Berdasarkan hal tersebut, maka penelitian ini akan dikembangkan sebuah 
media pembelajaran Pendidikan Agama Islam (PAI) berbasis web sebagai media belajar siswa Kelas VIII SMP Unismuh Makassar.

\section{METODE}

Metode penelitian ini adalah penelitian dan pengembangan (Research dan Development) untuk menghasilkan web yang diaplikasikan pada mata pelajaran Pendidikan Agama Islam (PAI). Model yang digunakan dalam penelitan dan pengembangan ini adalah model yang dikembangkan oleh S.Thiagarajan meliputi tahapan: Tahap pertama pendefinisian (define); Tahap pendefinisian sebagai landasan dalam penyusunan rancangan media pembelajaran. Kegiatan yang dilakukan dalam tahap ini adalah analisis awal-akhir, analisis siswa, analisis materi, analisis tugas, dan spesifikasi tujuan pembelajaran. Tahap kedua perancangan (design); tahap ini adalah untuk menyiapkan prototipe media berbasis web untuk pemecahan masalah. Tahap ini meliputi langkahlangkah pemilihan media, pemilihan format, dan rancangan awal pengembangan media. Tahap ketiga pengembangan (development); tahap ini adalah untuk menghasilkan media yang sudah direvisi berdasarkan masukan dari para pakar/ahli maupun setelah dilakukan uji coba. Tahap keempat penyebaran (Desseminate) pada tahapan ini tidak dilaksanakan, sehingga penelitian ini hanya dilakukan sampai tahap pengembangan saja. Teknik pengumpulan data sebanyak dua komponen yaitu observasi dan angket. Instrumen yang dikembangkan dalam penelitian ini adalah instrumen yang telah divalidasi oleh dua orang validator untuk menilai kesesuaian dengan indikator dan kelayakan penggunaannya. Pada penelitian dan pengembangan ini digunakan teknik analisis deskriptif untuk mengalisa data dengan cara mendeskripsikan atau mengambarkan data yang telah terkumpul dari hasil pengembangan, respon validator, aktivitas siswa, dan respon guru dan siswa dalam desain uji coba untuk memperoleh media pembelajaran berbasis web yang dikembangkan.

Data respon siswa dan guru diperoleh dari angket respon terhadap media pembelajaran berbasis web dalam proses pembelajaran. Selanjutnya dianalisis dengan analisis persentase. Secara rinci analisis berikut: a) Menghitung banyaknya siswa yang memberikan respon, b) Menentukan persentase kategori untuk respon positif siswa. Analisis respon siswa dan guru dapat dihitung dengan rumus:

$$
\operatorname{Pr}=\frac{n}{N} \times 100 \%
$$

Keterangan : 
Pr: Persentase respon; $n$ : Banyak siswa yang memberikan respon positif; $N$ : Banyak siswa yang mengisi angket respon siswa.

Untuk pengkategorian respon guru dan siswa tersebut digunakan kategori pada tabel 1 berikut :

Tabel 1. Kriteria Interpretasi Skor

\begin{tabular}{cc}
\hline Persentase (\%) & Kriteria \\
\hline$X \leq 25$ & Tidak Baik \\
$25<X \leq 50$ & Kurang Baik \\
$50<X \leq 75$ & Baik \\
$X>75$ & Sangat Baik \\
\hline & (Sumber: Riduwan, 2011)
\end{tabular}

\section{HASIL}

Hasil analisa pada tahapan Pendefenisian (define) analisis awalakhir, analisis siswa, analisis konsep, analisis tugas, dan spesifikasi tujuan pembelajaran melalui kegiatan pengamatan, diskusi dengan guru mata pelajaran Pendidikan Agama Islam (PAl) maka diperoleh gambaran bahwa penggunaan media pembelajaran yang belum optimal dan pembelajaran cenderung didominisi oleh guru sehingga membuat siswa merasa jenuh dan pasif dalam belajar. Melihat permasalahan tersebut, maka dapat dikatakan bahwa perlu untuk melaksanakan pengembangan media pembelajaran sebagai kebutuhan untuk mencapai tujuan pembelajaran yang telah ditetapkan.

Salanjutnya pada tahap ini perancangan (design) yang bertujuan untuk merancang prototipe media pembelajaran berbasis web untuk pemecahan masalah. Media yang digunakan dalam pelaksanaan pembelajaran menggunakan media pembelajaran berbasis website. Rancangan awal media pembelajaran ini merupakan prototipe yang akan dikembangkan, dari hasil design ini maka diperoleh prototipe media pembelajaran berbasis website yang kemudian akan dikembangkan melalui tahapan validasi, revisi dan uji coba terbatas. Rancangan awal berupa prototipe gambaran desain media pembelajaran Pendidikan Agama Islam (PAI) berbasis web bersifat sementara (hipotetik) yang akan di nilai oleh 2 (dua) orang ahli/pakar. Rancangan awal media pembelajaran meliputi: buku pedoman media pembelajaran, materi Pendidikan Agama Islam (PAI), media pembelajaran Pendidikan Agama Islam (PAl), lembar pengamatan aktivitas siswa, lembar respon guru, Rencana Pelaksanaan Pembelajaran (RPP), dan lembar respon siswa.

Pada tahap pengembangan (development) ini bertujuan untuk menghasilkan media pembelajaran yang sudah direvisi berdasarkan masukan dari para pakar maupun setelah dilakukan uji coba terbatas. 
Hasil validasi ahli dengan melibatkan dua orang validator ahli yang terdiri dari satu validator ahli materi dan ahli media. Hasil validasi ahli terhadap materi, media pembelajaran, instrumen respon guru, lembar aktivitas siswa, instrumen respon siswa dan Rencana Pelaksanaan Pembelajaran (RPP) terhadap media pembelajaran berbasis web memiliki "relevansi kuat" dengan koefesien validitas lebih dari $75 \%$ atau $V>75 \%$, sehingga hasil pengukuran yang dilakukan adalah sahih dan layak digunakan.

Sedangkan hasil kepraktisan media pembelajaran yang dikembangkan dapat diketahui berdasarkan aktivitas siswa, respon guru dan respon siswa siswa: Penilaian aktivitas siswa yaitu: 1) memperhatikan penejelasan guru, 2) memperhatikan materi pada media, 3) memberikan pertanyaan sebagai umpan balik terhadap penggunaan media, 4) menggunakan media pembelajaran web dengan baik, 5) mendiskusikan materi, dan 6) perilaku yang tidak relevan dengan kegiatan belajar menunjukkan bahwa hasil observasi aktivitas siswa dalam kegaiatan pembelajaran berada pada kriteria sangat aktif.

Hasil penilaian respon respon guru setelah menggunakan media pembelajaran. yang meliputi : 1) aspek kemenarikan, 2) aspek wana, 3) aspek suara dan 4) aspek gambar/ video. Hasil analisis data respon guru setelah melakukan pembelajaran dapat dilihat pada tabel 2 berikut:

Tebel 2. Hasil Analisi Respon Guru terhadap Media Pembelajaran Pelajaran Pendidikan Agama Islam (PAI) Berbasisis Web

\begin{tabular}{|c|c|c|c|c|c|}
\hline No. & Aspek & Kriteria Penilaian & Nilai & $\begin{array}{l}\text { Persentase } \\
\%\end{array}$ & Kategori \\
\hline \multirow{6}{*}{1.} & \multirow{6}{*}{ Kemenarikan } & $\begin{array}{l}\text { a. Tata letak konten dalam } \\
\text { web menarik perhatian }\end{array}$ & 4 & 100 & $\begin{array}{l}\text { Sangat } \\
\text { Baik }\end{array}$ \\
\hline & & $\begin{array}{l}\text { b. Tampilan dalam web } \\
\text { menarik perhatian }\end{array}$ & 3 & 75 & Baik \\
\hline & & $\begin{array}{l}\text { c. Cakupan materi dalam } \\
\text { web tutorial lengkap }\end{array}$ & 4 & 100 & $\begin{array}{l}\text { Sangat } \\
\text { Baik }\end{array}$ \\
\hline & & $\begin{array}{l}\text { d. Web sudah relevan } \\
\text { dengan materi yang } \\
\text { dipelajari }\end{array}$ & 3 & 75 & Baik \\
\hline & & $\begin{array}{l}\text { e. Menggunakan bahasa } \\
\text { yang komunikatif }\end{array}$ & 4 & 100 & $\begin{array}{l}\text { Sangat } \\
\text { Baik }\end{array}$ \\
\hline & & $\begin{array}{l}\text { f. Web tutorial mudah } \\
\text { digunakan }\end{array}$ & 4 & 100 & $\begin{array}{l}\text { Sangat } \\
\text { Baik }\end{array}$ \\
\hline \multirow{3}{*}{2.} & \multirow{3}{*}{ Warna } & $\begin{array}{l}\text { a. Warna layar depan } \\
\text { (gambar dan huruf) dalam } \\
\text { web menarik }\end{array}$ & 3 & 75 & Baik \\
\hline & & $\begin{array}{l}\text { b. Ketepatan pemilihan } \\
\text { warna dan teks }\end{array}$ & 3 & 75 & Baik \\
\hline & & $\begin{array}{l}\text { c. Keserasin warna gambar } \\
\text { tulisan dengan warna } \\
\text { baackground }\end{array}$ & 4 & 100 & $\begin{array}{l}\text { Sangat } \\
\text { Baik }\end{array}$ \\
\hline \multirow{2}{*}{3.} & \multirow{2}{*}{ Suara } & $\begin{array}{l}\text { a. Tata suara dalam web } \\
\text { tutorial menarik perhatian }\end{array}$ & 4 & 100 & $\begin{array}{l}\text { Sangat } \\
\text { Baik }\end{array}$ \\
\hline & & $\begin{array}{l}\text { b. Kejalasan audio dalam } \\
\text { menjelaskan materi }\end{array}$ & 4 & 100 & $\begin{array}{l}\text { Sangat } \\
\text { Baik }\end{array}$ \\
\hline
\end{tabular}




\begin{tabular}{llccc} 
& & & & $\begin{array}{l}\text { a. Gambar dan video } \\
\text { dalam web menarik } \\
\text { perhatian }\end{array}$ \\
b. Kejalasan gambar & 4 & 100 & $\begin{array}{c}\text { Sangat } \\
\text { Baik }\end{array}$ \\
& $\begin{array}{l}\text { G. Ketepatan ukuran } \\
\text { gambar }\end{array}$ & 3 & 75 & Baik \\
\hline Rata-rata & 3 & 75 & Baik \\
\hline
\end{tabular}

Berdasarkan hasil analisis dari tabel 2 respon guru diperoleh nilai rata-rata 3,57 (89\%) berada pada kategori sangat baik.

Sedangkan pada hasil analisis respon siswa terhadap media pembelajaran Pendidikan Agama Islam (PAI) berbasis web dapat dilihat pada tabel berikut :

Tabel 3. Hasil Analisis Respon Siswa terhadap Media Pembelajaran Pendidikan Agama Islam (PAl) Berbasis Web

\begin{tabular}{lcc}
\hline \multicolumn{1}{c}{ Kategori } & Frekuensi & Persentase (\%) \\
\hline Tidak Baik & 0 & 0 \\
Kurang Baik & 3 & 14 \\
Baik & 11 & 53 \\
Sangat Baik & 7 & 33 \\
\hline Jumlah & 21 & 100 \\
\hline Sumber : Analisis data respon siswa & &
\end{tabular}

Berdasarkan tabel 3 dapat dijelaskan bahwa dari 21 aspek ditanyakan kepada siswa 7 aspek atau $33 \%$ yang memenuhi kriteria sangat baik, 11 aspek atau $53 \%$ yang memenuhi krteria baik, ada 3 aspek atau 14\% memenuhi krteria kurang baik. Sehingga dapat dinyatakan bahwa respon siswa terhadap media pembelajaran Pendidikan Agama Islam (PAl) berbasis web berada pada kategori baik. Hal ini dapat di lihat pada diagram batang berikut: 


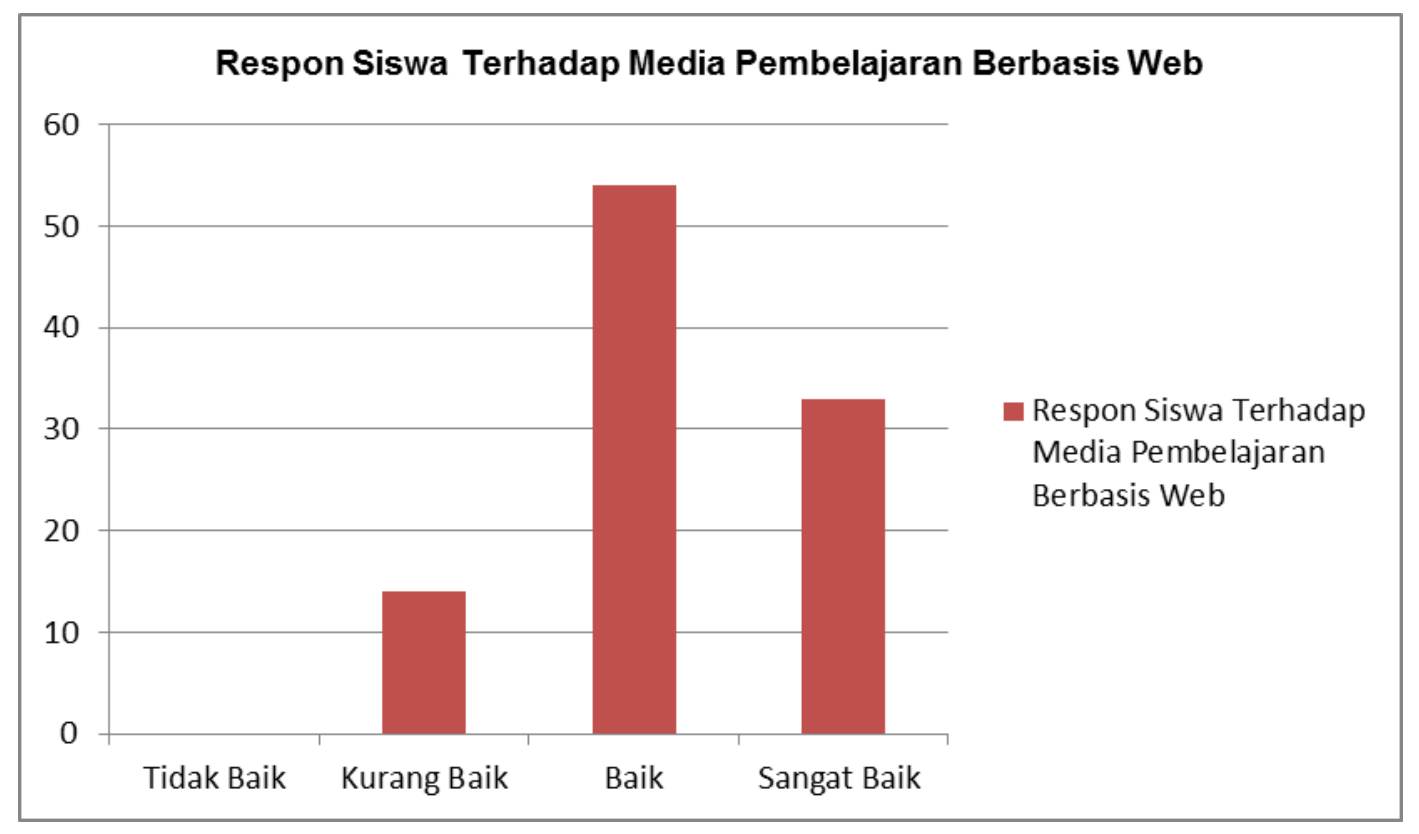

Gambar 1. Diagram Batang Respon Siswa terhadap Media Pembelajaran Pendidikan Agama Islam (PAI)

Berdasarkan hasil pengembangan dengan pertimbangan filosofis dimana media dikembangkan berdasarkan kebutuhan dalam proses pembelajaran sehingga mampu memberi manfaat bagi sekolah, guru dan siswa. Berdasarkan hasil pengembangan melalui tahapan validasi isi yang dilakukan oleh dua orang pakar merevisi hasil design dan memberikan penilaian sehingga hasil pengukuran yang dilakukan adalah sahih dan layak digunakan.

Dalam uji coba terbatas aktivitas siswa menunjukkan bahwa berdasarkan hasil observasi aktivitas siswa dalam kegiatan pembelajaran berada pada kriteria sangat aktif. Respon guru menunjukkan bahwa setelah melakukan kegiatan pembelajaran, guru memberikan respon baik pada media, sehingga media web dapat digunakan dan respon siswa setelah mengikuti kegiatan pembelajaran diperoleh kategori baik yang berarti bahwa media yang dikembangkan pada mata pelajaran pendidikan agama islam mendapatkan respon baik dari siswa. Sehingga dapat dikatakan bahwa dalam kegiatan pengembangan media pembelajaran memenuhi kriteria valid dan praktis digunakan dalam proses pembelajaran.

\section{PEMBAHASAN}

Media pembelajaran yang dikembangkan melalui serangkaian yakni, valiadasi ahli, revisi dan uji coba terbatas media pembelajaran sehingga dihasilkan media pembelajaran yang valid dan praktis. Hasil penilaian dari validator dikatakan bahwa keseluruhan komponen dalam 
penelitian yakni: a) validasi media, b) validasi materi, c) validasi angket respon guru, d) validasi observasi aktivitas siswa, e) validasi angket respon siswa, dan f) validasi rencana pelaksanaan pembelajaran dinyatakan valid dan sahih dengan revisi layak uji coba lapangan dengan revisi. Sehingga dilakukan revisi berdasarkan saran para ahli yang selanjutnya untuk diujicobakan.

Hasil uji coba terbatas untuk kriteria kepraktisan telah memenuhi kriteria, komponen kepraktisan media pembelajaran Pendidikan Agama Islam (PAI) berbasis web sesuai hasil pengamatan aktivitas siswa yang telah dianalisa untuk mengetahui frekuensi tiap kategori aktivitas siswa yang diamati selama pembelajaran berlangsung yaitu: memperhatikan penjelasan guru, memperhatikan materi pada media, memberikan pertanyaan sebagai umpan balik terhadap penggunaan media, menggunakan media pembelajaran berbasis web dengan baik, mendiskusikan materi, dan perilaku yang tidak relevan dengan kegiatan belajar menunjukkan bahwa hasil observasi aktivitas siswa dalam kegiatan pembalajaran berada pada kriteria sangat aktif sehingga dengan menggunakan media pembelajaran berbasis web siswa dapat belajar secara aktif. Hal tersebut tentu dapat mendorong guru untuk selalu memperhatikan strategi dalam penyampian pembelajaran. Sebagaimana yang telah dikemukan (Eva \& Iffah, 2019) dalam penelitiannya bahwa strategi pembelajaran mungkin baik untuk pokok bahasan tertentu atau situasi tertentu dan kondisi tertentu, tetapi mungkin tidak tepat untuk pokok bahasan dan situasi yang lain. Demikian pula suatu strategi pembelajaran dianggap tepat untuk siswa dengan karakteristik tertentu, sebaliknya strategi pembelajaran tidak tepat untuk karakteristik siswa yang lain. Disini guru dituntut untuk mampu menyesuaikan dengan keadaan lingkungan sekolah, karakteristik siswa, pokok bahasan agar bisa menerapkan strategi yang baik dan tepat digunakan untuk setiap kelas disesuaikan dengan karakteristik siswanya. Faktor lain yang mampu mempengaruhi minat belajar siswa yaitu faktor eksternal seperti suasana sekolah, suasana rumah, desain pembelajaran, strategi guru dalam menyampaikan pembelajaran serta sarana dan prasarana sekolah juga mampu membuat minat belajar siswa rendah. Dengan demikian media yang dikembangkan praktis digunakan dalam pembelajaran karena dapat memberikan dampak positif baik terhadap siswa. Sehingga dapat dismpulkan bahwa media tersebut telah memberikan rangsangan pada siswa.

Sedangkan Dari hasil analisis bahwa seluruh aspek yang dinyatakan dalam pelakasanaan pembelajaran dengan menggunakana media pembelajaran Pendidikan Agama Islam (PAI) berbasis web mendapat respon positif dari siswa dan guru. Kriteria kepraktisan berdasarkan respon siswa dari 21 aspek ditanyakan kepada siswa 7 aspek atau 33\% yang memenuhi kriteria sangat baik, 11 aspek atau 53\% yang memenuhi krteria baik, ada 3 aspek atau 14\% memenuhi kriteria kurang baik. Kriteria media web berdasarkan respon guru sama dengan 
kriteria keprakatisan berdasarkan respon siswa. Hasil analisis respon guru terhadap penggunaan media pembelajaran berbasis web dinyatakan mendapatkan repon positif/sangat baik oleh guru.

Kriteria media web berdasarkan respon guru sama dengan kriteria keprakatisan berdasarkan respon siswa. Hasil analisis respon guru terhadap penggunaan media pembelajaran berbasis web dinyatakan mendapatkan repon positif/sangat baik oleh guru. Sehingga dapat dikatakan bahwa media pembelajaran berbasis web dapat membantu guru dan mengarahkan siswa belajar dalam mencapai tujuan yang diinginkan. Inovasi pembelajaran yang memanfaatkan media internet/web sehingga pembelajaran dapat diminati oleh siswa maka guru diharapkan dapat menggunakan teknologi internet karena dapat menjadi alternatif dalam mendesain pembelajaran yang lebih menarik, interaktif, dan variatif (Agustin dan Samsudin, 2015).

Dari hasil uji coba pengembangan diperoleh hasil bahwa nilai keterlaksanaan media pembelajaran dapat dikatakan praktis karena semua komponen - komponen yang menjadi penilaian dalam observasi aktivitas siswa, respon guru dan siswa mendapat respon baik sehingga media tersebut memenuhi kriteria kepraktisan. Hal ini menunjukkan bahwa media pembelajaran yang telah dikembangkan dapat digunakan dalam pembelajaran Pendidikan Agama Islam (PAI) sesuai dengan materi yang telah ditentukan.

Beberapa temuan yang diperoleh peneliti selama pelaksanaan uji coba pengembangan media pembelajaran berbasis web dapat diuraikan sebagai berikut : 1) Pada tahap pelaksanaan uji coba terbatas media pembelajaran, masih ada sebagian siswa yang belum bisa menggunakan media hal ini disebabkan karena kemungkinan tidak terbiasa dengan penggunaan benda elektronik. 2) Tingkat keaktifan siswa di dalam pelaksanaan pembelajaran sangat tinggi. Hal ini disebabkan karena siswa memperhatikan penjelasan guru dan materi pada media pembelajaran berbasis web, sehingga siswa tidak melakukan hal - hal yang tidak relevan dengan kegiatan pembelajaran. 3) Dapat meningkatkan motivasi belajar siswa untuk mengikuti proses pembelajaran.

\section{KESIMPULAN}

Hasil yang diperoleh dilapangan terhadap pelaksanaan pembelajaran Pendidikan Agama Islam (PAl), menunjukkan bahwa sangat penting media pembelajaran untuk dikembangkan dalam mengatasi permasalahan, media yang dikembangkan dalam mengatasi permasalahan adalah media pembelajaran Pendidikan Agama Islam (PAI) berupa website.Hasil pengembangan melalui tahapan validasi yang dilakukan oleh dua orang pakar merevisi hasil design dan memberikan penilaian sehingga hasil pengukuran yang dilakukan adalah sahih dan layak digunakan dengan sedikit revisi. Dalam uji coba terbatas aktivitas siswa menunjukkan bahwa aktivitas siswa dalam kegiatan pembelajaran 
berada pada kriteria sangat aktif. Respon guru menunjukkan bahwa setelah melakukan kegiatan pembelajaran, guru memberikan respon sangat baik pada media yang dikembangkan dan respon siswa diperoleh kategori baik. Sehingga dapat dikatakan bahwa hasil pengembangan media pembelajaran memenuhi kriteria valid dan praktis digunakan dalam proses pembelajaran Pendidikan Agama Islam (PAI).

\section{Saran}

Berdasarkan hasil penelitian, pembahasan dan kesimpulan, kesimpulan maka penulis menyarankan agar :1) hasil penelitaian ini hanya pada sampai tahap develop uji coba terbatas. Oleh karena itu disarankan pada penelitiaan selanjutnya agar dapat mengimplementasikan lebih luas lagi pada sekolah lainnya melalui tahap desseminate sehingga mendapatkan hasil yang lebih baik dan lebih mendalam. 2) Guru Pendidikan Agama Islam (PAI) diharapkan dapat menerapkan media pembelajaran tidak hanya dalam materi ibadah haji dan umroh tetapi pada materi lain yang sesuai dalam pembelajaran agar siswa dapat termotivasi untuk mempelajari lebih dalam materi yang dipelajari. 3) Bagi sekolah agar lebih menyiapkan sarana dan prasarana sehingga proses pembelajaran lebih efektif dengan menggunakan media pembelajaran berbasis web.

\section{DAFTAR PUSTAKA}

Agusti \& Samsudin. (2015). Pengaruh Strategi Pembelajaran Bermedia Internet dan Minat Belajar Siswa Terhadap Hasil Belajar Kognitif Keterampilan Komputer Dan Pengelolaan Informasi (KKPI). Akdemika Jurnal Teknologi Pendidikan 4 (2):45-60

Arif, M, Khairan \& Verawati. (2017). Pengembangan Modul Pembelajaran Dengan Model Dick And Carey Pada Pelajaran Pendidikan Agama Islam bagi Siswa Kelas 5 Di SDIT lqro. Akdemika Jurnal Teknologi Penddiikan 6 (2): 71-89

Azhar, Arsyad. (2011). Kreatif Mengembangkan Media Pembelajaran. Jambi: Gaung Persada Press

Dewi Salma. (2012). Wawasan Teknologi Pendidikan , Jakarta: Kencana Prenada Media Group

Kristiani, Eva \& Budiningsih Iffah, (2019). Pengaruh Strategi Pembelajaran E-Learning Dan Minat Belajar Terhadap Hasil Belajar Akuntansi. Akademika Jurnal Teknologi Pendidikan 8 (1): 57-69 
Miarso Yusufhadi. (2009). Menyemai Benih Teknologi Pendidikan. Jakarta: Kencana

Muhaimin. (2012). Paradigma Pendidikan Islam, Bandung : Rosda

Mukhtar. (2003). Desain Pembelajaran PAl, Jakarta: Misaka Galiza

Muslim \& Yasin. Fahri M. (2018). Pengaruh Media ICT Dan Kecerdasan Linguistik Terhadap Hasil Belajar Bahasa Inggris (Studi Eksperimen Pada Peserta Diklat Tingkat Menengah Di Pusdiklat Bahasa Badiklat Kementerian Pertahanan Jakarta). Akademika Jurnal Teknologi Pendidikan 7 (1): 72-92

Nusa, Putra. (2013). Research and Development. Depok: Rajagrafindo Persada.

Riduwan. (2011). Skala Pengukuran Variabel - Variabel Penelitian. Bandung: Alfabeta

Rusman. (2013). Pembelajaran Berbasis Teknologi Informasi dan Komunikasi. Jakarta: Rajawali Pers

Sharon E. Smaldino, Deborah L. Lowther, James D. Russel. (2011). "Instructional Technology and Media For Learning. Kencana Prenada Media Group

Thiagarajan, Sivasailam, Dorothy S. Semmel, Melvin I. Semmel. (1974). Instructional Development for Training Teachers of exceptional Children. Indiana: Indiana University

Trianto. (2013). Mendesai Model Pembelajaran Inovatif-Progresif. Jakarta: Kencana

Uno, Hamzah.B. (2014). Assesment Pembelajaran. Jakarta : Bumi Aksara

Yasdin. (2013). Pengembangan media e-elearning berbasis web jurusan pendidikan teknik otomotif fakultas teknik UNM. Tesis. tidak dterbitkan. Makassar : PPs UNM 